\title{
Dental health care providers' concerns, perceived impact, and preparedness during the COVID-19 pandemic in Saudi Arabia
}

\author{
Muhammad Qasim Javed ${ }^{\text {Corresp., } 1}$, Farooq Ahmad Chaudhary ${ }^{2}$, Syed Fareed Mohsin ${ }^{3}$, Mustafa Hussein AlAttas ${ }^{1}$, \\ Hadeel Yaseen Edrees ${ }^{4}$, Syed Rashid Habib ${ }^{5}$, Arham Riaz ${ }^{6}$ \\ ${ }^{1}$ Department of Conservative Dental Sciences and Endodontics, College of Dentistry, Qassim University, Buraidah, Qassim, Saudi Arabia \\ Department of Community Dentistry, School of Dentistry, Shaheed Zulfiqar Ali Bhutto Medical University, Islamabad, Pakistan \\ 3 Department of Oral Maxillofacial Surgery and Diagnostic Sciences, College of Dentistry, Qassim University, Ar Rass, Qassim, Saudi Arabia \\ 4 Endodontic Department, Faculty of Dentistry, King Abdulaziz Univeristy, Jeddah, Saudi Arabia \\ 5 Department of Prosthetic Dental Sciences, College of Dentistry, King Saud University, Riyadh, Saudi Arabia \\ 6 Community Dentistry, Academy of Continuing Health Education and Research, Islamabad, Pakistan \\ Corresponding Author: Muhammad Qasim Javed \\ Email address: M.Anayat@qu.edu.sa
}

Background: Dental health care providers (DHCPs) are at high risk of cross-infection during clinical practice therefore, the aim of the study was to evaluate the DHCPs Covid-19 related concerns, its perceived impact, and their preparedness in Saudi Arabia. Methods: This cross-sectional study on DHCPs was carried out at five dental teaching hospitals/colleges in four provinces of Saudi Arabia from October to December 2020. A 35 items valid and reliable questionnaire was used to assess the concerns, perceived impact, and preparedness of DHCPs in the COVID-19 pandemic. Chi-square tests and logistic regression were used to compare parameters between the clinical and non-clinical staff. Results: A total of 320 DHCPs participated in this study with proportion of clinical staff (57.5\%) surpassing the non-clinical staff (42.5\%). The clinical DHCPs felt greater odds of falling ill with COVID-19 than non-clinical workers (OR, 2.61) and willing to look for another job (OR, 3.50). The higher proportion in both groups was worried that people close to them would be at higher exposure risk (96.3\%) however, slightly more clinical DHCPs were concerned for their children than a non-clinical worker (OR, 3.57). The clinical DHCPs have greater odds of worrying that people would avoid them and their family members because of their job (OR, 2.75). A higher proportion in both groups $(75.0 \%, 63.2 \%)$ felt that they would feel stress at work. More non-clinical DHCPs (94.1\%) had received training for infection control than clinical (94.1\% vs 63.0\%: OR 0.10). Similarly, more DHCPs in the nonclinical group received adequate personal protective equipment training (88.2\%; OR, 0.48). Most participants practiced self-preparation such as buying masks and disinfection (94.4\%, 96.9\%). Conclusion: The majority of DHCPs felt concerned about their risk of exposure and falling ill from infection and infecting friends/family. These concerns could 
potentially affect the working of DHCPs during this pandemic. Measures to improve protection for DHCPs, minimize psychological implications, and potential social stigmatization should be identified at the planning phase before any pandemic. 
1 Dental health care providers' concerns, perceived impact, and preparedness during the

2 COVID-19 pandemic in Saudi Arabia.

3 Muhammad Qasim Javed ${ }^{1}$, Farooq Ahmad Chaudhary ${ }^{2}$, Syed Fareed Mohsin ${ }^{3}$, Mustafa Hussein

4 AlAttas $^{4}$, Hadeel Yaseen Edrees ${ }^{5}$, Syed Rashid Habib ${ }^{6}$, Arham Riaz

$5{ }^{1}$ Assistant Professor, Department of Conservative Dental Sciences and Endodontics, College of 6 Dentistry, Qassim University, Buraydah, Qassim,Saudi Arabia.

$7{ }^{2}$ Assistant Professor, Department of Community Dentistry, School of Dentistry, Shaheed 8 Zulfiqar Ali Bhutto Medical University, Islamabad, Pakistan.

$9{ }^{3}$ Associate Professor, Department of Oral Maxillofacial Surgery and Diagnostic Sciences, 10 College of Dentistry, Qassim University, Ar Rass, Saudi Arabia.

$11{ }^{4}$ Assistant Professor, Department of Conservative Dental Sciences and Endodontics, College of 12 Dentistry, Qassim University, Buraydah, Qassim,Saudi Arabia.

$13{ }^{5}$ Assistant Professor, Endodontic Department, Faculty of Dentistry, King Abdulaziz Univeristy, 14 Saudi Arabia.

15 'Professor, Department of Prosthetic Dental Sciences, College of Dentistry, King Saud 16 University, Saudi Arabia.

$17{ }^{7}$ Lecturer, Community Dentistry, Academy of Continuing Health Education and Research, 18 Islamabad, Pakistan

19 Corresponding Author:

20 Muhammad Qasim Javed

21 Assistant Professor, College of Dentistry, Qassim University, Buraydah, PO Box 6700, 51452,

22 Qassim, Saudi Arabia

23 Email address: M.Anayat@qu.edu.sa 


\section{Abstract}

26

27

28

Background: Dental health care providers (DHCPs) are at high risk of cross-infection during clinical practice therefore, the study aimed to evaluate the DHCPs Covid-19 related concerns, its perceived impact, and their preparedness in Saudi Arabia.

Methods: This cross-sectional study on DHCPs was conducted at five dental teaching hospitals/colleges in four provinces of Saudi Arabia from October to December 2020. A 35 items reliable and valid adopted questionnaire was used to assess the concerns, perceived impact, and preparedness of DHCPs in the COVID-19 pandemic. Chi-square and logistic regression tests were used for analysis.

Results: A total of 320 DHCPs took part in this study with proportion of clinical staff (57.5\%) surpassing the non-clinical staff (42.5\%). The clinical DHCPs felt greater odds of falling ill with COVID-19 than non-clinical workers (OR, 2.61) and willing to look for another job (OR, 3.50). The higher proportion in both groups was worried that people close to them would be at higher exposure risk (96.3\%) however, slightly more clinical DHCPs were concerned for their children than a non-clinical worker (OR, 3.57). The clinical DHCPs have greater odds of worrying that people would avoid them and their family members because of their job (OR, 2.75). A higher proportion in both groups $(75.0 \%, 63.2 \%)$ felt that they would feel stress at work. More nonclinical DHCPs (94.1\%) had received training for infection control than clinical $(94.1 \%$ vs 63.0\%: OR 0.10). Similarly, more DHCPs in the nonclinical group received adequate personal protective equipment training $(88.2 \%$; OR, 0.48). Most participants practiced self-preparation such as buying masks and disinfection $(94.4 \%, 96.9 \%)$. 
46 Conclusion: The majority of DHCPs felt concerned about their risk of exposure and falling ill

47 from infection and infecting friends/family. These concerns could potentially affect the working 48 of DHCPs during this pandemic. Measures to improve protection for DHCPs, minimize 49 psychological implications, and potential social stigmatization should be identified at the 50 planning phase before any pandemic.

51 Keywords: Concerns, COVID-19, preparedness, Dental health care providers, Dental hospitals

\section{Introduction:}

By the end of 2019, the COVID-19 outbreak in Wuhan, China made global headlines and continued to spread globally at a rapid speed ${ }^{1}$. The World Health Organization (WHO) had declared the COVID-19 outbreak, a pandemic on the 11th of March 2020². Currently, the virus has affected 221 countries and territories with approximately, 102 million individuals have been infected with the virus worldwide, with a mortality rate of $2.1 \%{ }^{3}$ The Saudi Ministry of Health reported the first COVID-19 case on $2^{\text {nd }}$ March 2020, when an individual returning from Iran was tested positive ${ }^{4}$ As of 1st February 2021, the Kingdom of Saudi Arabia has reported about 368,074 confirmed cases. The total recovered patients are 359,573, with 6375 deaths in the kingdom. Overall, the positive cases to PCR test, (12,295,687 tests) ratio are around 3\%.5

It is highly communicable pathogen that can be easily transmitted via virus-laden respiratory droplets of the infected individual. ${ }^{6}$ In this context, National Health Services England and American Dental Association issued guidelines for Dental health care providers (DHCPs) and suggested that all elective dental treatments should be postponed and only patients with dental emergencies should be accommodated. ${ }^{7,8}$ With the total sum of patients who have contracted 
68 COVID-19 disease approaching 102 million globally, it is almost certain that some of the 69 infected individuals will need emergency dental care ${ }^{3}$. Considering that the evidence supporting 70 the use and effectiveness of antibiotics for acute dental conditions (pulpal and periapical pain) is 71 weak $^{9}$, it seems that DHCPs will have to carry out the acute dental care for the known or suspected COVID-19 patients. The guidelines for the dental management of COVID-19 patients are continuously evolving and the outbreak has placed DHCPs at a very high risk of acquiring nosocomial infections. The bio-aerosols produced during dental procedures have the potential to float in the air for a considerable period. ${ }^{10}$ A recently published review has discussed in detail the necessary requirements of personal protective equipment (PPE), administrative, and environmental control for the provision of acute dental care in the current circumstances. ${ }^{11}$ It is recommended that suspected or confirmed COVID-19 patients should not be treated in the neutral pressure rooms of routine dental practices. Instead, the aforementioned patient group should only be treated in airborne infection isolation rooms or negative pressure treatment 81 rooms. $^{12}$

With the increased risk of exposure to DHCPs due to the close contact with the COVID-19 infected patients' oropharyngeal region and distinctive features of dental treatment procedures that involve aerosol generation, routine infection control measures in dental practice are not adequate to prevent the COVID-19 spread. ${ }^{13}$ Consequently, Dental healthcare facilities have made the use of PPE mandatory while treating patients. The enhanced exposure risk among

87 healthcare workers (HCWs), results in stress and fear of contracting the infection. ${ }^{14,15}$ A study in Poland showed that $71.2 \%$ of the dentist voluntarily suspended their practice due to fear, anxiety and unpreparedness of oral health care sector both at public and private settings for COVID-19 
91 hospital perceived their health to be at risk and this increased their stress and impacted their

92 clinical performance ${ }^{17}$ According to Amnesty international COVID-19 disease has resulted in the

93 death of around 7000 healthcare professionals, globally with lack of PPE as one of the

94 contributory factors. ${ }^{18}$

95 In Saudi Arabia, several HCWs have lost their lives as a result of COVID-19 disease

96 complications and many more suffering from psychological morbidities. ${ }^{19}$ Previous reports on

97 COVID-19 infection related concerns and its impact involved the medical health care workers

98 only, little is understood about the oral health care workers despite facing similar challenges and

99 occupational hazards. Only one study in Pakistan reported the dental health care providers

100 COVID-19 related concerns, its impact and preparedness in dental hospitals ${ }^{20,21}$. More studies

101 are needed to be carried out to understand the difference in concerns, perceived impact and

102 preparedness of DHCPs working in different socioeconomics and geographical regions.

103 Therefore, the objective of the study was to evaluate the perceived impact, preparedness, and

104 concerns of dental healthcare providers during the COVID-19 disease pandemic in the dental

105 hospitals of Saudi Arabia

106 Materials and Methods:

107 The current cross-sectional study was conducted at five dental teaching hospitals/colleges in four

108 provinces (Qassim, Riyadh, Jeddah, Eastern Province) of the Kingdom of Saudi Arabia from

109 October to December 2020. The ethical approval for this research was taken from the Dental

110 Ethics Committee of Qassim University (Reference Code: ST/6080/2020). A convenient

111 sampling technique was used to recruit the respondents. All the participants voluntarily

112 participated in the study; the identified participants were contacted by an appointed staff at the

113 respective institutions/hospital. The purpose of the study was explained by sharing the 
114 information sheet with DHCPs at the dental hospitals. A written informed consent was obtained, 115 and participants were requested to self-administered the study questionnaire. The first part of the 116 questionnaire collected information regarding socio-demographic characteristics of the 117 participants which included age, gender, marital status, place of work, and place of living. A 118 valid and reliable questionnaire consisting of 35-items in four sections was adopted from 119 Chaudhary et al., (2020) to assess the concerns, perceived impact, and preparedness of DHCPs in 120 the COVID-19 pandemic. The concerns related to work and social life of DHCPs were assess in 121 the first two sections of the adopted questionnaire and perceived impact and preparedness of 122 DHCPs was assess in the last two sections. The participants recorded their responses on a 6-point 123 Likert scale ranges from 1 (strongly agree, agree, and probably agree) to 6 (strongly disagree, 124 disagree, and probably disagree). The responses were dichotomized, former 3 responses were 125 recoded as agree and the latter 3 as disagree for the purpose of analysis. The DHCPs were 126 classified into two subgroups: non-clinical (basic sciences faculty, managerial/clerical staff, 127 dental lab technician, attendant/cleaners) and clinical (faculty and consultants of clinical 128 subjects, general dentists, dental hygienists, and assistants) depending upon their direct 129 interaction with the patients..

\section{Statistical analysis}

131 SPSS version 23 (SPSS Institute, Chicago, IL, USA) was used for the statistical analysis.

132 Descriptive statistics were calculated for all variables. The chi-square tests were used to evaluate 133 the association between socio-demographics variables with clinical and non-clinical staff. 134 Binary logistic regression adjusted for socio-demographics variables were used to compare the 135 parameter between non-clinical and clinical staff. The level of significance was set at $<0.05$.

136 Results: 
137 The questionnaires were distributed among 350 subjects however only 320 (91.4\%) participants

138 were able to complete all the questions. A slight exceeding number of Clinical staff $(\mathrm{n}=184$, $13957.5 \%)$ participated in the study as compared to non-clinical staff $(n=136,42.5 \%)$. The majority 140 of participants in both the groups were below the age of 40 years $(54 \%, 94.1 \%)$, A significantly 141 higher proportion of non-clinical male staff was found than clinical staff $(p<0.001)$. Similarly, 142 the majority of participants in both the groups were working in the government sector $(87.3 \%)$, 143 and significantly higher proportion of non-clinical staff living with friends and family compared 144 to clinical staff $(\mathrm{P}<0.001)$. The demographic characteristics of dental healthcare providers are 145 shown in Table 1.

146 A higher proportion of clinical DHCPs were afraid of falling ill with COVID-19 than non147 clinical workers (90.2\% vs $77.9 \%$; OR, 2.61; 95\% CI, 1.38- 4.91). However, 69.6\% of DHCPs 148 in this study think that they should not be looking after COVID-19 patients and only $57.5 \%$ of 149 DHCPs felt that this risk of exposure is not acceptable. However, a majority (80.4\%) of them accepted the risk of contracting COVID-19 as part of the job. Very small proportions from both 151 groups were looking for another job because of this risk (7.4\%), but more clinical DHCPs were 152 willing to look for another job than non-clinical DHCPs $(21.7 \%$ vs $11.0 \%$; OR, 3.50; 95\% CI, 153 1.68- 7.28), and a minority of them think that it's acceptable if colleagues resign because of the 154 fear $(42.5 \%)$ (Table 2).

155 The higher proportion in both groups were worried that people close to them would be at higher 156 exposure risk (96.3\%), and more concerned were related to spouse/partner, parents, close friends, 157 and work colleagues in both groups $(90.0 \%, 96.9 \%, 97.5 \%$, and 95.0\%). However, slightly more 158 clinical workers were concerned for their children than a non-clinical worker (97.8 \% vs $92.6 \%$; 159 OR, 3.57; 95\% CI, 1.09-11.6) (Table 3). 
160 More clinical workers were afraid that people would avoid them and their family members 161 because of their job than non-clinical workers (65.2 vs 44.1; OR, 2.37; 95\% CI, $1.50-3.74$ and 16247.8 vs 25.0 ; OR, 2.75; 95\% CI, 1.69-4.46). More than half of the participants (55.6\%) in both 163 groups felt that there is an inadequate staff at their workplace to handle increase demand and 164 similarly the same percentage of participants in both the groups $(55.6 \%)$ felt that there would be 165 more conflict among colleagues at their workplace. A higher proportion of clinical workers $166(75.0 \%)$ than non-clinical workers $(63.2 \%)$ think that they would feel stress at work (OR, 1.74; 167 95\% CI, 1.07-2.82). (Table 4)

168 Participants in both the groups (87.5\%) know that there is an infection control committee \& staff 169 in the hospital, but more non-clinical workers $(94.1 \%)$ had received training for infection control 170 at the hospital than clinical workers (94.1\% vs $63.0 \%$; OR 0.10; 95\% CI, 0.04- 0.23). Similarly, 171 more nonclinical workers knew about preparedness plan for Covid-19 outbreak than clinical 172 workers (80.9\% vs $64.1 \%$, OR 0.42: 95\% CI, 0.25-0.71).

173 Participants in both the groups bought disinfection equipment (94.4\%) and masks (96.9). 174 However, more DHCPs in the nonclinical group received adequate personal protective 175 equipment training than clinical DHCPs (88.2\% vs 78.3\%; OR, 0.48; 95\% CI, 0.25-0.90)(Table $1765)$.

177 Discussion:

178 This study investigates the perceived impact and preparedness of dental health care providers 179 during the COVID-19 pandemic in Saudi Arabia. Greater percentage of participants was from Al 180 Qasim region (54.3\%) as two participating Dental teaching institutes/hospitals were from Qassim 181 region. Moreover, there are some other factors that might have resulted in the high response rate 
182 from Qassim region, such as comprehensive COVID 19 related online awareness/training

183 program for the staff members and students organized by the infection control unit at college of

184 Dentistry and multiple reminders that were sent to the potential participants.

185 This study reports that a higher percentage of clinical DHCPs were afraid of falling ill with

186 COVID-19 than non-clinical workers. Our finding is in line with other studies on HCWs in

187 Singapore during the Avian Influenza outbreak and oral healthcare workers in Pakistan. ${ }^{22,23}$

188 Since it has been confirmed that the main route for coronavirus transmission is through droplets, 189 the probability of oral healthcare workers being infected is increasing ${ }^{24}$. In this study majority of 190 clinical DHCPs (70\%) think that they should not be looking after COVID-19 patients, however, 191 a higher proportion of DHCPs $(86.3 \%)$ felt that contracting COVID-19 infection is a part of the 192 job. These findings are in agreement with previous studies on health workers where the majority 193 agreed that contracting an infection during the job is part of their profession and they are at high 194 risk of contracting the virus. The plausible explanations may be related to a higher awareness of 195 DHCPs provided by social media networks about high-risk factors, their outcome, other factors 196 like shortages of personal protective equipment (PPE) in hospitals, extended workloads, 197 insufficient testing, and other emerging issues ${ }^{23}$.

198 A small number of DHCPs (7.4\%) reported that they would look for another job. The response is 199 consistent with other studies conducted in Singapore, the USA, and Pakistan, where most 200 healthcare workers agreed to continue work during SARS, Avian influenza, and COVID-19 201 outbreak respectively ${ }^{22,25}$. In contrast, other studies reported a higher proportion of healthcare 202 workers from Taiwan, Hong Kong, and the United Kingdom (43\%-77\%) refused to work during 203 an outbreak and preferred to look for another job or quit their job $26,27,28$ 
204 A significant proportion of participants in both groups responded that people close to them 205 would be at higher exposure risk. In contrast, clinical workers were more concerned about 206 exposure risk to their children than non-clinical workers. These findings were observed during 207 the SARS outbreak as well, where media reported discrimination against HCWs and their family members ${ }^{29,30}$. In the present COVID-19 pandemic, many countries effectively highlighted the dedication and sacrifices offered by HCWs ${ }^{31}$. This strategy has changed public opinion resulting in supporting their effort of serving the people and the country. Law enforcement agencies in Pakistan have also gave the Guard of Honour and one month honorarium as a token of appreciation to HCWs for their hard work, dedication and contribution as a front liner in the battle against COVID-19 ${ }^{32}$. However, the results of this study indicate that the perception and fear of prejudice against health workers are still sustained, and more efforts should be done to change people's perceptions.

More than half of the respondents reported that there was inadequate clinical staff to handle increasing demand. Moreover, a higher proportion of clinical workers were under stress when compared to non-clinical workers. These findings are consistent with other studies where hospitals were overwhelmed with the patients and insufficient health staff was working extra hours to handle this load. This workload along with fear of exposure to COVID-19 to them and their family members made health workers more stressed and worried as shown in this study ${ }^{23}$.

222 Both clinical and non-clinical DHCPs involved in infection control activities and seemed to be more aware of their preparedness plan however, a greater proportion of non-clinical DHCPs 224 (66.2\%) attended infection control training sessions recently than clinical DHCP (47.8\%). This result is in contrast with the study in Pakistan where more clinical oral health workers attended infection control training sessions than non-clinical oral health workers. One of the plausible 
227 reason for this disparity may be that the personal preparedness of clinical oral health workers in

228 Saudi Arabia is much better (73.9\%) compared to clinical oral health workers in Pakistan

$229(30.9 \%)$ and secondly, the majority of DHCPs $(87.5 \%)$ in this study knew about the working of

230 infection control committee in the hospital than in Pakistan $(51.3 \%) .{ }^{22,23}$ The DHCPs are at high

231 risk for this disease and therefore need sufficient training not just as precautionary but also to

232 show confidence and high morality while at work. Many countries have established criteria for

233 provision of oral care services during this pandemic, including training of control infections and

234 establishing safety protocols that should be part of infection control in dental hospitals ${ }^{33}$.

235 The WHO has highlighted the importance of preparedness plans to mitigate the adverse impact

236 of this pandemic and like many other countries Saudi Arabia have also prepare and implement

237 their national pandemic Covid-19 preparedness plan based on WHO guidelines ${ }^{34,35}$. These

238 guidelines ensuring adequate support for frontline health and oral health care workers, including

239 access to prevention, treatment, and provision of medications or vaccines. The breakthrough in

240 this pandemic is the invention of the vaccine and many countries, including Saudi Arabia, have

241 started administering the COVID-19 vaccine as the priority to frontline health and oral health

242 care workers and people with chronic diseases to combat this deadly disease and keep high hope

243 to control this infection. Moreover, in case of financial constraints because of the exponential

244 spread of COVID-19 disease the infection control for the DHCPs' can be achieved by

245 implementing the frugal solutions. ${ }^{36}$

246 The cross-sectional study design and use of self-administered questionnaires have their

247 limitations such as recall, framing, and rating bias. This research's main strength was that it was

248 the first study that explored the concerns, impacts, and preparedness of DHCPs in Saudi Arabia 
249 during the COVID-19 pandemic. This study will help to contribute to the development of further

250 studies on DHCPs related to COVID-19.

\section{Conclusion:}

252 This study revealed that DHCP are extremely vulnerable to the risk of the COVID-19 infection

253 resulting in infecting family and friends due to their profession. The majority of DHCPs were

254 well prepared for this pandemic both personally and at the workplace. The concerns observed in

255 this study could ultimately affect the overall efficiency of oral health care workers during a

256 pandemic. Measures to improve protection for DHCPs, minimize psychological implications,

257 and potential social stigmatization should be identified at the planning phase before any

258 pandemic.

\section{References:}

1) Zhu H, Wei L, Niu P: The novel coronavirus outbreak in Wuhan, China. Global health research and policy 2020, 5(1):1-3.

2) Cucinotta D, Vanelli M: WHO declares COVID-19 a pandemic. Acta bio-medica: Atenei Parmensis 2020, 91(1):157-160.

3) Khan AM, Nawabi S, Javed MQ. Dental Faculty's Knowledge and Attitude Regarding $18 ; 20(4): 1202-10$. 
268

269

270

271

272

273

274

275

276

277

278

279

280

281

282

283

284

285

286

287

288

289

4) National Health Services England (2020) Letters, updates and additional guidance for dental teams; Available at: https://www.england.nhs.uk/coronavirus/publication/ preparedness -letters-for-dental-care/

5) The American Dental Association (2020) Coronavirus resource toolkit for ADA members. Available at: https://www.ada.org/en/membercenter/coronavirus-resourcetoolkit-for-ada-members.

6) World Health Organization. Coronavirus disease 2019 (COVID-19) situation report. Available at: https://www.who.int/emergencies/diseases/novel-coron avirus2019/situation-reports. Accessed 12 May, 2020

7) Ministry of Health. MOH Reports First Case of Coronavirus Infection. Available at: https://www.moh.gov.sa/en/Ministry/MediaCenter/News/Pages/News-2020-03-02002.aspx

8) Ministry of Health.COVID-19 dashboard, Saudi Arabia. Available at: https://covid19. moh.gov.sa/

9) Lockhart PB, Tampi MP, Abt E, Aminoshariae A, Durkin MJ, Fouad AF, Gopal P, Hatten BW, Kennedy E, Lang MS, Patton LL.. Evidence-based clinical practice guideline on antibiotic use for the urgent management of pulpal-and periapical-related dental pain and intraoral swelling: A report from the American Dental Association. JADA. 2019;150: 906-921.

10) Occupational Safety and Health Administration. Occupational Safety and Health Administration (OSHA) guidelines. 2020. Available at https://www.osha.gov/Publications/OSHA3990.pdf. 
290

291

292

293

294

295

296

297

298

299

300

301

302

303

304

305

306

307

308

309

310
11) Ather A, Patel B, Ruparel NB, Diogenes A, Hargreaves KM.. Coronavirus disease 19 (COVID-19): implications for clinical dental care. J Endod.2020; 46:584-595.

12) Centers for Disease Control and Prevention. Infection control: severe acute respiratory syndrome coronavirus 2 (SARS-CoV-2).2020. Available at: https:/www.cdc.gov/coronavirus/2019-ncov/infection-control/controlrecommendations.html. Accessed 9 March, 2020.

13) Kohn WG, Collins AS, Cleveland JL, Harte JA, Eklund KJ, Malvitz DM. Guidelines for infection control in dental health-care settings.2003. Available at https://stacks.cdc.gov/view/cdc/6743

14) Dubey S, Biswas P, Ghosh R, Chatterjee S, Dubey MJ, Chatterjee S, Lahiri D, Lavie CJ.. Psychosocial impact of COVID-19. Diabetes Metab Syndr. 2020;14(5):779-788.

15) Boyraz G, Legros DN. Coronavirus disease (COVID-19) and traumatic stress: probable risk factors and correlates of posttraumatic stress disorder. J Loss Trauma. 2020; 25(67):503-522.

16) Amnesty International. Global: Amnesty analysis reveals over 7,000 health workers have died from COVID-19. Available at: https://www.amnesty.org/en/latest/news/2020/09/amnesty-analysis-7000-health-workershave-died-from-covid19/

17) Arab news. Saudi government to grant 500,000 riyals to families of health workers who died from COVID-19. Available at: https://www.arabnews.com/node/1755021/saudiarabia 
311

312

313

314
18) Wong TY, Koh GC, Cheong SK, Lee HY, Fong YT, Sundram M, Koh K, Chia SE, Koh D. Concerns, perceived impact and preparedness in an avian influenza pandemic-a comparative study between healthcare workers in primary and tertiary care. Ann Acad Med Singap. 2008;37(2):96.

19) Chaudhary, FA, Ahmad, B, Ahmad, P, Khalid, MD, Butt, DQ, Khan, SQ. Concerns, perceived impact, and preparedness of oral healthcare workers in their working environment during COVID-19 pandemic. J. Occup. Health. 2020; 62:e12168. https://doi.org/10.1002/1348-9585.12168

20) Ge, Z.; Yang, L.; Xia, J.; Fu, X.; Zhang, Y. Possible aerosol transmission of COVID-19 and special precautions in dentistry. J. Zhejiang Univ. B 2020, 1-8,

21) Martin SD. Nurses' ability and willingness to work during pan- demic flu. J Nurs Manag. 2011;19(1):98-108

22) Wong EL, Wong SY, Kung K, Cheung AW, Gao TT, Griffiths S. Will the community nurse continue to function during H1N1 influenza pandemic: a cross-sectional study of Hong Kong community nurses? BMC Health Services Research. 2010;10(1):107.

23) Shiao JS-C, Koh D, Lo L-H, Lim M-K, Guo YL. Factors predict- ing nurses' consideration of leaving their job during the SARS out- break. Nursing Ethics. 2007;14(1):5-17.

24) Barr H, Macfarlane J, Macgregor O, Foxwell R, Buswell V, Lim W. Ethical planning for an influenza pandemic. Clin Med. 2008;8(1):49. 
331

332
25) Khee KS, Lee LB, Chai OT, Loong CK, Ming CW, Kheng TH. The psychological impact of SARS on health care providers. Critical Care and Shock. 2004;100-106.

26) Tai DY. SARS plague: duty of care or medical heroism? Ann Acad Med Singap. 2006;35(5):374.

27) Tang SKJA.New ways for Singaporeans to offer help and support amid outbreak of COVID-19. Available at: https://www.channelnewsasia.com/ news/singapore/covid-19coronavirus-new-ways-for-singaporea ns-to-offer-help-12427792. Accessed 13 May, 2020

28) News T.Law enforcers present guard of honour to doctors, nurses fighting COVID-19. Available at: https://www.thenews.com.pk/print/639039-law-enforcers-present-guard-ofhonour-to-doctors-nurses-fight ing-covid-19. Accessed 14 May, 2020

29) Ahmed MA, Jouhar R, Ahmed N, Adnan S, Aftab M, Zafar MS, Khurshid Z. Fear and practice mod- ifications among dentists to combat Novel Coronavirus Disease (COVID19) outbreak. Int J Environ Res Public Health. 2020;17(8):2821.

30) MOH,COVID-19 Guidelines. Available at: https://www.moh.gov.sa/en/Ministry/ Media Center/Publications/Pages/covid19.aspx

31)WHO. Strategic preparedness and response plan. Available at: https:/www.who.int/ publications/i/item/strategic-preparedness-and-response-plan-for-the-new-coronavirus

32) Javed M, Bhatti Y. Frugal solutions. British Dental Journal. 2020;229(8):499. 
Table $\mathbf{1}$ (on next page)

Demographic Characteristics of Dental Healthcare Professionals 
1

\begin{tabular}{|c|c|c|c|}
\hline & $\begin{array}{c}\text { Clinical Staff N(\%) } \\
N=184(57.5)\end{array}$ & $\begin{array}{c}\text { Non-Clinical staff } N(\%) \\
N=136(42.5)\end{array}$ & $\begin{array}{l}\text { Chi-square } \\
\text { (P-Value) }\end{array}$ \\
\hline $\begin{array}{l}\text { Age } \\
20-29 \\
30-39 \\
40-49 \\
50-60 \\
60-70 \\
\end{array}$ & $\begin{array}{l}34(18.5) \\
64(34.8) \\
62(33.7) \\
16(8.7) \\
8(4.3) \\
\end{array}$ & $\begin{array}{l}128(94.1) \\
0 \\
6(4.4) \\
0 \\
2(1.5) \\
\end{array}$ & 0.001 \\
\hline $\begin{array}{l}\text { Gender } \\
\text { Male } \\
\text { Female }\end{array}$ & $\begin{array}{l}110(60.0) \\
74(40.2)\end{array}$ & $\begin{array}{l}110(81.0) \\
26(19.1)\end{array}$ & 0.001 \\
\hline $\begin{array}{l}\text { Civil status } \\
\text { Single } \\
\text { Married } \\
\text { Divorced } \\
\end{array}$ & $\begin{array}{l}44(23.9) \\
136(73.9) \\
4(2.2)\end{array}$ & $\begin{array}{l}118(86.8) \\
18(13.2) \\
0\end{array}$ & 0.001 \\
\hline $\begin{array}{l}\text { Place of work } \\
\text { Government/public-Sec. } \\
\text { Private sector }\end{array}$ & $\begin{array}{l}154(83.7) \\
30(16.3)\end{array}$ & $\begin{array}{l}136(100.0) \\
0\end{array}$ & 0.001 \\
\hline $\begin{array}{l}\text { Staying with } \\
\text { Family/friend } \\
\text { Alone }\end{array}$ & $\begin{array}{l}136(73.9) \\
48(26.1)\end{array}$ & $\begin{array}{l}128(94.1) \\
8(5.9)\end{array}$ & 0.001 \\
\hline $\begin{array}{l}\text { Location } \\
\text { Qasim } \\
\text { Riyadh } \\
\text { Jeddah } \\
\text { Eastern Province }\end{array}$ & $\begin{array}{l}92(50.0) \\
12(6.5) \\
42(22.8) \\
38(20.7) \\
\end{array}$ & $\begin{array}{l}82(60.3) \\
22(16.2) \\
16(11.8) \\
16(11.8)\end{array}$ & 0.001 \\
\hline
\end{tabular}

2

3 
Table 2 (on next page)

COVID-19 Pandemic and Work-related concerns of Dental Healthcare Professionals 
1

\begin{tabular}{|c|c|c|c|c|c|c|c|}
\hline Concerns (Agree) & $\begin{array}{l}\text { Clinical } \\
\mathbf{N}(\%)\end{array}$ & $\begin{array}{c}\text { Non- } \\
\text { clinical } \\
\text { N(\%) } \\
\end{array}$ & $\begin{array}{l}\text { Total } \\
\mathbf{N}(\%)\end{array}$ & Unadjusted OR & $\begin{array}{c}\text { P- } \\
\text { value }\end{array}$ & $\begin{array}{l}\text { Adjusted } \\
\text { OR* }\end{array}$ & $\begin{array}{c}\text { P- } \\
\text { value }\end{array}$ \\
\hline \multicolumn{8}{|l|}{ Work-related concerns } \\
\hline My job would put me at great exposure risk & $166(90.2)$ & $130(95.6)$ & $296(92.5)$ & $0.12(0.02-0.57)$ & 0.007 & $0.42(0.16-1.10)$ & 0.07 \\
\hline I am afraid of falling ill with Covid-19 & $166(90.2)$ & $106(77.9)$ & $272(85.0)$ & $2.16(0.80-5.80)$ & 0.12 & $2.61(1.38-4.91)$ & 0.003 \\
\hline I should not be looking after Covid-19 patients & $128(69.6)$ & $68(50.0)$ & $196(61.3)$ & $3.66(1.68-7.95)$ & 0.001 & $2.28(1.44-3.62)$ & 0.001 \\
\hline The risk I am exposed to is not acceptable & $116(63.0)$ & $68(50.0)$ & $184(57.5)$ & $1.49(0.75-2.98)$ & 0.251 & $1.70(1.08-2.67)$ & 0.020 \\
\hline $\begin{array}{l}\text { I accept that risk of contracting Covid-19 is } \\
\text { part of job }\end{array}$ & $148(80.4)$ & $128(94.1)$ & $276(86.3)$ & $0.43(0.15-1.24)$ & 0.119 & $0.25(0.11-0.57)$ & 0.001 \\
\hline Might look for another job because of risk & $40(21.7)$ & $10(11.0)$ & $50(7.4)$ & $3.77(1.40-10.1)$ & 0.008 & $3.50(1.68-7.28)$ & 0.001 \\
\hline $\begin{array}{l}\text { Acceptable if colleagues resign because of their } \\
\text { fear }\end{array}$ & $74(40.2)$ & $62(45.6)$ & $136(42.5)$ & $0.68(0.34-1.36)$ & 0.28 & $0.80(0.51-1.25)$ & 0.33 \\
\hline $\begin{array}{l}\text { Health care employers would look after my } \\
\text { needs if I fall ill with Covid-19 }\end{array}$ & $140(76.1)$ & $106(77.9)$ & $246(76.9)$ & $1.27(0.59-2.73)$ & 0.532 & $0.90(0.53-1.52)$ & 0.69 \\
\hline
\end{tabular}

$2{ }^{*}$ Adjusted for age, gender, Marital status, Place of work, Staying with. 


\section{Table 3 (on next page)}

COVID-19 Pandemic and Non-work Related Concerns of Dental Healthcare Professionals 
2

\begin{tabular}{|l|l|l|l|l|l|l|l|}
\hline Concerns (Agree) & $\begin{array}{l}\text { Clinical } \\
\mathbf{N}(\mathbf{\%})\end{array}$ & $\begin{array}{l}\text { Non-clinical } \\
\mathbf{N}(\mathbf{\%})\end{array}$ & $\begin{array}{l}\text { Total } \\
\mathbf{N}(\mathbf{\%})\end{array}$ & $\begin{array}{l}\text { Unadjusted OR } \\
\text { value }\end{array}$ & $\begin{array}{l}\text { Adjusted } \\
\text { OR* }\end{array}$ & $\begin{array}{l}\text { P- } \\
\text { value }\end{array}$ \\
\hline Non-work concerns & & & & & & \\
\hline $\begin{array}{l}\text { People close to me would be at high risk } \\
\text { of getting Covid- 19 because of my job }\end{array}$ & $174(94.6)$ & $134(98.5)$ & $308(96.3)$ & $0.55(0.07-4.10)$ & 0.56 & $0.26(0.56-1.20)$ & 0.085 \\
\hline $\begin{array}{l}\text { I would be concerned for my: } \\
\text { Spouse/partner }\end{array}$ & $174(94.6)$ & $114(83.8)$ & $288(90.0)$ & $1.84(0.58-5.83)$ & 0.29 & $3.35(1.53-7.35)$ & $\mathbf{0 . 0 0 2}$ \\
\hline Parents & $176(95.7)$ & $134(98.5)$ & $310(96.9)$ & $0.76(0.12-4.76)$ & 0.77 & $0.32(0.06-1.57)$ & 0.16 \\
\hline Children & $180(97.8)$ & $126(92.6)$ & $306(95.6)$ & $3.39(0.68-16.9)$ & 0.13 & $3.57(1.09-11.6)$ & $\mathbf{0 . 0 3 5}$ \\
\hline Close friends & $176(95.7)$ & $136(100.0)$ & $312(97.5)$ & - & - & - & - \\
\hline Work colleagues & $176(95.7)$ & $128(94.1)$ & $304(95.0)$ & $0.52(0.12-2.26)$ & 0.38 & $1.37(0.50-3.76)$ & 0.53 \\
\hline $\begin{array}{l}\text { People close to me would be worried for } \\
\text { my health }\end{array}$ & $178(96.7)$ & $132(97.1)$ & $310(96.9)$ & $0.56(0.10-3.10)$ & 0.508 & $0.89(0.24-3.25)$ & 0.87 \\
\hline $\begin{array}{l}\text { People close to me would be worried as } \\
\text { they may get infected by me }\end{array}$ & $178(96.7)$ & $132(97.1)$ & $310(96.9)$ & $0.56(0.10-3.10)$ & 0.50 & $0.89(0.24-3.25)$ & 0.87 \\
\hline
\end{tabular}

3 * Adjusted for age, gender, Marital status, Place of work, Staying with. 
Table 4 (on next page)

Dental Healthcare Professionals' Perceived impact on work and Personal Life 
1

\begin{tabular}{|c|c|c|c|c|c|c|c|}
\hline Perceived impact (agree) & $\begin{array}{l}\text { Clinical } \\
\mathrm{N}= \\
\%\end{array}$ & $\begin{array}{l}\text { Non- } \\
\text { clinical } \\
\mathrm{N}= \\
\%\end{array}$ & $\begin{array}{l}\text { Total } \\
\mathrm{N}= \\
\%\end{array}$ & $\begin{array}{l}\text { Unadjusted } \\
\text { OR }\end{array}$ & $\begin{array}{l}\text { P- } \\
\text { value }\end{array}$ & $\begin{array}{l}\text { Adjusted } \\
\text { OR* }\end{array}$ & P-value \\
\hline $\begin{array}{l}\text { I would be afraid of telling my family/friends } \\
\text { about the risk I am exposed }\end{array}$ & $90(48.9)$ & $64(47.1)$ & $154(48.1)$ & $1.75(0.88-3.49)$ & $\mathbf{0 . 1 0}$ & $1.07(0.69-1.67)$ & 0.74 \\
\hline People would avoid me because of my job & $120(65.2)$ & $60(44.1)$ & $180(56.3)$ & $4.50(2.54-7.97)$ & 0.001 & $2.37(1.50-3.74)$ & 0.001 \\
\hline $\begin{array}{l}\text { People would avoid my family members because } \\
\text { of my job }\end{array}$ & $88(47.8)$ & $34(25.0)$ & $122(38.1)$ & $2.44(1.21-4.89)$ & 0.012 & $2.75(1.69-4.46)$ & 0.001 \\
\hline $\begin{array}{l}\text { I would avoid telling other people about the nature } \\
\text { of my job }\end{array}$ & $48(26.1)$ & $22(16.2)$ & $70(21.9)$ & $7.79(3.18-19.0)$ & 0.001 & $1.82(1.04-3.21)$ & 0.035 \\
\hline $\begin{array}{l}\text { There would be inadequate staff at my workplace } \\
\text { to handle the increased demand }\end{array}$ & $120(65.2)$ & $58(42.6)$ & $178(55.6)$ & $2.66(1.29-5.48)$ & 0.008 & $2.52(1.59-3.97)$ & 0.001 \\
\hline $\begin{array}{l}\text { There would be more conflict amongst colleagues } \\
\text { at work }\end{array}$ & $108(58.7)$ & $70(51.5)$ & $178(55.6)$ & $1.37(0.70-2.67)$ & 0.34 & $1.34(0.85-2.09)$ & 0.19 \\
\hline I would feel more stressed at work & $138(75.0)$ & $86(63.2)$ & $224(70.0)$ & $4.54(2.0-10.2)$ & 0.001 & $1.74(1.07-2.82)$ & 0.024 \\
\hline I would have an increase in workload & $134(72.8)$ & $88(64.7)$ & $222(69.4)$ & $2.38(1.12-5.06)$ & 0.024 & $1.46(0.90-2.35)$ & 0.12 \\
\hline I would have to do work not normally done by me & $108(58.7)$ & $68(50.0)$ & $176(55.0)$ & $1.47(0.75-2.90)$ & 0.025 & $1.42(0.91-2.20)$ & 0.12 \\
\hline
\end{tabular}

$2{ }^{*}$ Adjusted for age, gender, Marital status, Place of work, Staying with.

3

4

5

6

7

8

9

10 


\section{Table 5 (on next page)}

Preparedness of Dental Healthcare Professionals for COVID-19 Pandemic 
1

\begin{tabular}{|c|c|c|c|c|c|c|c|}
\hline Statement (agree) & $\begin{array}{l}\text { Clinical } \\
\mathbf{N}(\%)\end{array}$ & $\begin{array}{c}\text { Non- } \\
\text { clinical } \\
\text { N(\%) }\end{array}$ & $\begin{array}{l}\text { Total } \\
\text { N(\%) }\end{array}$ & Unadjusted OR & $\begin{array}{c}\text { P- } \\
\text { value }\end{array}$ & $\begin{array}{l}\text { Adjusted } \\
\text { OR* }\end{array}$ & $\begin{array}{c}\text { P- } \\
\text { value }\end{array}$ \\
\hline $\begin{array}{l}\text { There is an infection control committee \& staff in } \\
\text { my hospital }\end{array}$ & $154(83.7)$ & $126(92.6)$ & $280(87.5)$ & $0.22(0.08-0.64)$ & 0.005 & $0.40(0.19-0.86)$ & 0.019 \\
\hline $\begin{array}{l}\text { I have received training for infection control at my } \\
\text { hospital }\end{array}$ & $116(63.0)$ & $128(94.1)$ & $244(76.3)$ & $0.10(0.037-0.27)$ & 0.001 & $0.10(.049-0.23)$ & 0.001 \\
\hline $\begin{array}{l}\text { My clinic has a preparedness plan for a Covid-19 } \\
\text { outbreak }\end{array}$ & $118(64.1)$ & $110(80.9)$ & $228(71.3)$ & $0.50(0.23-1.06)$ & 0.074 & $0.42(0.25-0.71)$ & 0.001 \\
\hline $\begin{array}{l}\text { My hospital has informed me of their Covid-19 } \\
\text { outbreak preparedness plan }\end{array}$ & $116(63.0)$ & $90(66.2)$ & $206(64.4)$ & $1.13(0.56-2.30)$ & 0.718 & $0.87(0.54-1.38)$ & 0.56 \\
\hline I am personally prepared for a Covid-19 outbreak & 136(73.9) & $122(89.7)$ & $258(80.6)$ & $0.68(0.29-1.62)$ & 0.39 & $0.32(0.17-0.61)$ & 0.001 \\
\hline \multicolumn{8}{|l|}{ In the past 6 months } \\
\hline I have attended infection control training sessions & $88(47.8)$ & $90(66.2)$ & $178(55.6)$ & $0.54(0.27-1.08)$ & 0.082 & $0.46(0.29-0.74)$ & 0.001 \\
\hline Bought disinfection & 174(94.6) & $128(94.1)$ & $302(94.4)$ & $0.72(0.17-2.97)$ & 0.65 & $1.08(0.41-2.83)$ & 0.86 \\
\hline Bought masks & $180(97.8)$ & $128(95.5)$ & $308(96.9)$ & $0.81(0.10-6.18)$ & 0.84 & $2.10(0.58-7.62)$ & 0.25 \\
\hline $\begin{array}{l}\text { Received adequate personal protective equipment } \\
\text { training }\end{array}$ & $116(63.0)$ & $112(82.4)$ & $228(71.3)$ & $0.51(0.23-1.11)$ & 0.09 & $0.36(0.21-0.62)$ & 0.001 \\
\hline $\begin{array}{l}\text { Have someone to turn to if unsure of use of } \\
\text { personal protective equipment }\end{array}$ & $144(78.3)$ & $120(88.2)$ & $264(82.5)$ & $1.65(0.67-4.07)$ & 0.27 & $0.48(0.25-0.90)$ & 0.022 \\
\hline
\end{tabular}

$2 *$ Adjusted for age, gender, Marital status, Place of work, Staying with.

3

4

5

6

7

8 